- Almost half of dental unit water systems (DUWS) sampled harboured viable microorganisms at levels greater than current guidelines.

underestimated the total microbial load.

- Endotoxin levels in water were low.

- ATP is a very rapid method of indirectly detecting the microbial load, but the method is currently not sufficiently sensitive to reliably detect the normal levels of microbes in DUWS.

\title{
Total viable counts, ATP, and endotoxin levels as potential markers of microbial contamination of dental unit water systems
}

\author{
M. R. Fulford, ${ }^{1}$ J. T. Walker, ${ }^{2}$ M. V. Martin ${ }^{3}$ and P. D. Marsh ${ }^{4}$
}

Objectives To determine if either ATP or endotoxin concentrations in water supplied by dental unit water systems (DUWS) correlated with total viable counts (TVC), and therefore could be used as a rapid, chairside measure of levels of microbial contamination.

Design A prospective trial.

Method Fifty-seven water samples were taken from the 'triple spray', air rotor and source water supplies from 25 dental units in eight practices. The samples were assayed for endotoxin concentration, total ATP and TVC. A pilot study was performed to assess the relationship between TVC and total cell counts, as determined by flow cytometry.

Results ATP concentrations ranged from 22 to 958 relative light units (RLU) and free endotoxin ranged from 25 to $600 \mathrm{EU} \mathrm{ml}^{-1}$. TVC varied from not detected to $2.16 \times 10^{4} \mathrm{CFU} \mathrm{ml^{-1 }}$. The ATP method proved to be a simple and rapid method that could be used at the chairside. However, there was no correlation between ATP or endotoxin concentrations and TVC in DUWS. TVC generally underestimated the total cell count by 50 to 500 fold.

Conclusion Half of the water samples from DUWS exceeded recommended levels of TVC. However, ATP and endotoxin concentrations in DUWS water samples did not correlate with these TVC data and therefore could not be recommended as an alternative assay to TVC for measuring bacterial contamination or for monitoring water treatment efficacy.

Dental unit water systems (DUWS) are generally contaminated with bacteria. $7,9,13,15$ The normal method of measuring bacterial contamination is by total viable counts (TVC) following culture on microbiological media in a dedicated laboratory. This is a time-

\footnotetext{
${ }^{1}$ GDP, 10 B Lower Downside, Shepton Mallet, Somerset, BA4 4JX; ${ }^{2 *}$ Project Team Leader Health Protection Agency, Porton Down, Salisbury SP4 4JG; ${ }^{3}$ Senior Lecturer and Honorary Consultant Microbiologist, Department of Clinical Dental Sciences, University of Liverpool, Liverpool L69 3BX; ${ }^{4}$ Professor and Scientific Leader, Health Protection Agency, Porton Down, Salisbury SP4 0JG and Professor of Oral Microbiology, Leeds Dental Institute, Leeds LS2 9LU

${ }^{*}$ Correspondence to: Dr J. T. Walker, Health Protection Agency, Porton Down Salisbury SP4 OJG

Email:jimmy.walker@hpa.org.uk
}

\section{Refereed Paper}

doi:10.1038/sj.bdj.4810943

Received: 10.10.02; Accepted: 07.05.03

$\odot$ British Dental Journal 2004; 196: 157-159 consuming and labour intensive process, and there is an inevitable delay before the data are available and can be acted upon. In order for the bacterial counts to be as accurate as possible, it is essential to ensure that the samples are processed without delay after collection. This may prove difficult if the site of collection is remote from the microbiology laboratory.

In the brewing and food industry, bacterial and other cellular contamination is estimated by measuring total adenosine triphosphate (ATP). ${ }^{4,5}$ Hygiene monitoring using ATP also offers a simple and valuable means of monitoring dental practice cleaning routines. ${ }^{6}$ This test is relatively simple to perform and can be done at the site of sampling. The simplicity and rapidity of the ATP test system are features that could potentially make this a feasible approach to measure contamination of DUWS at the chairside. This would be particularly useful in confirming the efficacy of decontamination procedures.

Another potential method of estimating TVC could be to measure endotoxin concentration. Much of the bacterial contamination of DUWS is by Gram-negative bacteria, which on lysis would release endotoxin. Thus, endotoxin estimation could potentially also be used as a measure of bacterial contamination of DUWS. This assay is used extensively in the pharmaceutical industry for testing the production of endotoxin-free water.

The purpose of this study was to:

- Evaluate the use of rapid, commercial kits to estimate ATP

- Assess a laboratory-based endotoxin assay

- Determine whether the data generated by ATP and endotoxin analysis would correlate with TVC in DUWS, and

- Investigate if they have potential as simpler approaches to determine levels of DUWS contamination.

\section{MATERIALS AND METHODS}

\section{Water samples from DUWS}

For a pilot study, ten water samples from a general dental practice were analysed in order to establish the relationship between TVC and total cell counts. Subsequently, in the study of the water in GDPs, 57 water samples were collected aseptically from both the triple spray handpiece and the air rotor connector in 25 primary care surgeries in South West England. The sterile sample bottles 
contained $0.1 \mathrm{~g}$ of sodium thiosulphate to neutralise any chlorine present in the sample (Abinghurst Ltd, UK). The water samples were transported in a cool box to the laboratory and were tested within $3 \mathrm{~h}$ of collection.

\section{TVC of water samples}

A water sample of $100 \mathrm{ml}$ was passed through a $0.45 \mu \mathrm{m}$ cellulose acetate filter (Techware, Poole, UK). The filter was then placed in a sterile container, containing $10 \mathrm{ml}$ of sterile water, and agitated vigorously to re-suspend any organisms trapped on the filter surface. Ten-fold dilutions from neat to $10^{-2}$ were made of the supernatant fluid in PBS containing sodium thiosulphate (3.5 g per l) and $0.1 \mathrm{ml}$ of each dilution was then surface plated onto Yeast Extract agar (Biomerieux, UK) for total viable counts (TVC) and MacConkey agar (Biomerieux, UK) for coliform counts. All plates were then incubated at $37^{\circ} \mathrm{C}$ for $72 \mathrm{~h}$. Colonies were counted using a plate counter and the TVC for each sample was calculated. The level of detection was $10 \mathrm{CFU} \mathrm{ml}^{-1}$.

\section{Total microbial cell count}

Samples taken during the pilot study were analysed in counting chambers under light microscopy using the improved Neubauer, Kova and Thoma slides. In addition, the total number of microbial cells present in $1.0 \mathrm{ml}$ of each water sample were also analysed using flow cytometry (Beckman Coulter Epics XL) with fluorescent beads as a background control. Bacterial and bead populations were separated on a forward scatter v side scatter plot. Maximum total events were set at 15,000. Data were collected for each sample to determine cell numbers per $\mathrm{ml}$.

\section{ATP assays}

ATP was measured in the original water sample, using the AquaTrace ${ }^{\mathrm{TM}}$ system (Biotrace, Cardiff, UK). This detects and quantifies luminescence of a luciferase/ATP reaction in a photometer and gives a value in relative light units (RLU) proportional to the quantity of ATP present. The device is in the form of a plastic swab that contains reagents to lyse intact cells to release the ATP and is designed to sample the correct volume of water for the reaction. The swab is then placed back into the plastic container and pushed to the bottom of the tube which contains the reagents for the reaction. The tube is then shaken gently and placed into the portable Uni-Lite ${ }^{\mathrm{TM}}$ reading device (Biotrace, Cardiff, UK) which measures the amount of light released by the reaction, and the value is printed out. Before each batch of tests was performed the Uni-Lite device was calibrated with no AquaTrace reaction to measure any background luminescence $(<10$ RLU). The detection limit of the system is approximately $10^{3}$ CFU $\mathrm{ml}^{-1}$.

\section{Endotoxin assay}

Separate water samples were collected into plastic endotoxin- and pyrogen-free universal containers. The samples were filtered through a $0.45 \mu \mathrm{m}$ cellulose acetate filter (Sartorius Ltd., UK), which removes intact bacteria but allows free endotoxin to remain in suspension, and stored at $-4^{\circ} \mathrm{C}$ until tested. The water samples were analysed using a Limulus Amoebocyte Lysate (LAL) gel-clot reagent (Charles River Laboratories) and recorded in endotoxin units $\mathrm{ml}^{-1}\left(\mathrm{EU} \mathrm{ml} \mathrm{m}^{-1}\right)$. Initially, the filtered water samples were screened at $150 \mathrm{EU} \mathrm{ml}^{-1}$ by diluting the samples 1:600. Any positive reactions were further diluted to give sensitivities of 300, 600 and $1,200 \mathrm{EU} \mathrm{ml}^{-1}$. Those samples that gave negative reactions were reanalysed to test at sensitivities of 25,50 and $100 \mathrm{EU} \mathrm{ml}^{-1}$. These were titrated against a control standard Escherichia coli endotoxin of known potency $\left(0.25 \mathrm{EU} \mathrm{ml}^{-1}\right)$ (Charles River Laboratories). Tests were incubated at $37^{\circ} \mathrm{C}$ for 60 minutes; positive reactions were recorded for those tubes that contained a firm gel-clot that remained in place when the tube was inverted. All tests and dilutions were performed in endotoxin-free glass test tubes (Charles River Laboratories) using LAL reagent water $(<0.001 \mathrm{EU}$ $\mathrm{ml}^{-1}$ ) (Charles River Laboratories). Each batch of tests contained both positive and negative controls and the method used for the assay meant that the sensitivity for the test was $>25 \mathrm{EU} \mathrm{ml}^{-1}$.

\section{Statistical analysis}

Statistical analysis was carried out using Pearsons (rank-order) Correlation Coefficient Test.

\section{RESULTS}

\section{Pilot study}

Microbial numbers were too low in the water samples to obtain reliable cell counts using the conventional counting chambers and therefore flow cytometry was used to assess the total cell count more accurately. Total microbial counts as measured by flow cytometry were generally higher than TVC by 50 to 500 fold, with extremes of 7-, 1,925- and 10,709-fold (Table 1). TVC exceeded $100 \mathrm{CFU} \mathrm{ml} \mathrm{m}^{-1}$ in $9 / 10$ samples taken during the pilot study. One sample was from a stagnant unit (number 5, Table 1) and resulted in both a high TVC, total count and ATP. The ATP assay was shown to have good reproducibility when replicate samples from the same water source were analysed (Table 2).

\begin{tabular}{|c|c|c|c|}
\hline Sample & $\begin{array}{c}\text { TVC }\left(\log _{10} \mathrm{CFU} \mathrm{ml}^{-1}\right) \\
(\text { mean } \pm \text { SD }) \\
n=6\end{array}$ & $\begin{array}{c}\text { Total cell count } \\
\left.\text { (Log } \log _{10} \text { number per } \mathrm{ml}\right) \\
(\text { mean } \pm \text { SD }) \\
n=6\end{array}$ & $\begin{array}{c}\text { ATP (RLU) } \\
\left(\log _{10} \text { mean } \pm \text { SD }\right) \\
n=6\end{array}$ \\
\hline 1 & $2.29 \pm 0.15$ & $6.34 \pm 0.49$ & $2.74 \pm 0.01$ \\
\hline 2 & $2.50 \pm 0.59$ & $5.40 \pm 0.14$ & $2.32 \pm 0.01$ \\
\hline 3 & $2.88 \pm 0.36$ & $5.13 \pm 0.01$ & $2.64 \pm 0.01$ \\
\hline 4 & $3.76 \pm 0.04$ & $5.37 \pm 0.15$ & $2.59 \pm 0.01$ \\
\hline 5 & $4.50 \pm 0.40$ & $6.63 \pm 0.53$ & $3.41 \pm 0.32$ \\
\hline 6 & $3.11 \pm 2.20$ & $5.51 \pm 0.18$ & $2.56 \pm 1.80$ \\
\hline 7 & $3.32 \pm 0.71$ & $4.85 \pm 0.06$ & $2.18 \pm 0.19$ \\
\hline 8 & $1.82 \pm 0.09$ & $5.11 \pm 0.07$ & $2.61 \pm 0.06$ \\
\hline 9 & $3.22 \pm 0.10$ & $5.80 \pm 0.04$ & $2.55 \pm 0.09$ \\
\hline 10 & $2.59 \pm 0.20$ & $5.38 \pm 0.09$ & $2.54 \pm 0.06$ \\
\hline
\end{tabular}

$\begin{aligned} & \text { Table } 2 \text { Multiple ATP analyses of four water samples to evaluate the } \\
& \text { reproducibility of Aquatrace Bioluminescence systems }\end{aligned}$
\begin{tabular}{lccc} 
Sample & $\begin{array}{c}\text { ATP(RLU) } \\
\left(\begin{array}{c}\text { mean } \pm \text { SD }) \\
n=6\end{array}\right.\end{array}$ & $\begin{array}{c}\text { ATP (RLU) } \\
\text { (Range) }\end{array}$ & TVC CFU ml ${ }^{-1}$ \\
\hline 1 & $837 \pm 117$ & $722-967$ & 1016 \\
\hline 2 & $552 \pm 132$ & $446-763$ & 1512 \\
\hline 3 & $1050 \pm 308$ & $767-1448$ & 432 \\
\hline 4 & $2561 \pm 1550$ & $1071-5041$ & 1860
\end{tabular}

\section{Practitioner study}

The TVC ranged from not detectable to $2.16 \times 10^{4} \mathrm{CFU} \mathrm{m}^{-1}$ (mean $\left.=1.3 \times 10^{3}\right)$ (Fig. 1). None of the samples produced growth on MacConkey agar, while 10 samples gave no colonies on Yeast Extract agar (Fig. 1). The ATP assay was quick and easy to use, and values ranged from 22 to 958 RLU. The automatic print-out meant that there was a record of the data. In contrast the endotoxin assay test was semi-quantitative and required specialist laboratory glassware and equipment to perform. Results took at least 


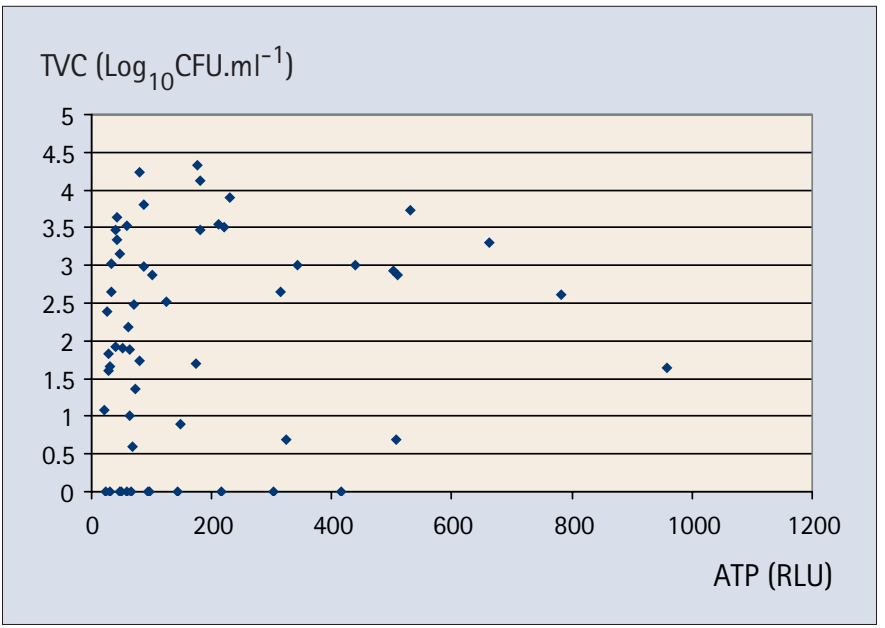

Fig. I Scatter plot of TVC versus ATP from 50 water samples from GDP DUWS

one hour to obtain and for economic reasons were best performed on a batch basis. Only 11/57 samples had detectable levels of endotoxin (range $=0-300 \mathrm{EU} \mathrm{ml}^{-1}$ ); these positive samples were not related to high TVCs or the presence of coliforms.

Analysis of the relationship between TVC and ATP analysis was performed using Microsoft Excel (Fig. 1). Statistical analysis using Pearsons (rank-order) Correlation Coefficient Test indicated that the correlation, at 0.006, was not significant $(P=0.98)$ and that the correlation, at 0152, between the TVC and total cell counts in the pilot study was also not significant $(P=0.676)$.

\section{DISCUSSION}

A recent study in the UK has shown that as many as 93\% of GDP DUWS would fail to deliver water that would conform to EU potable water standard of $100 \mathrm{CFU} \mathrm{ml}^{-1} .{ }^{15}$ In addition, $87 \%$ of the units sampled would have failed to meet current ADA DUWS standards of 200 CFU ml ${ }^{-1}{ }^{2}$ Chairside tests would offer the opportunity to both monitor water quality and assess the efficacy of any adopted preventative regime. Conventional microbiology is time-consuming, expensive and inevitably there is a lag between sample taking and provision of results, during which time patients will continue to be treated using water that may not fulfil published guidelines.

The majority of the organisms found in the planktonic phase of DUWS are derived from a biofilm that forms on the internal surfaces of tubing within the dental unit. $3,10,14,15$ The accurate recovery of viable microorganisms from aquatic systems is problematical. For example, it has been reported that it may only be possible to recover $5 \%$ of the organisms from DUWS by conventional cultural techniques ${ }^{12}$ with recovery from other ecosystems being as low as $0.001 \% .{ }^{1}$ Therefore, the extent of the contamination of DUWS may be underestimated when based on TVC. Our pilot study confirmed this, and found the ratio of cultured/total cell counts to be in the same range as that reported for other environmental aquatic ecosystems. ${ }^{1}$ This may be one reason why the TVC, ATP and endotoxin assay did not correlate. The problem in culturing all bacteria has led to the proposal that ATP levels may be more representative of the contamination of the water than the TVC. However, there were samples where high TVC were found, but only a relatively low ATP value was recorded. This may be due to the rapid degradation of ATP by the release of cellular ATP'ases. More work is required to explain the lack of direct correlation between TVC and ATP before this approach could be adopted.

The endotoxin assay method used in this study was relatively expensive and required specialist expertise and equipment and therefore may not be practical for use in the dental surgery. Very few of the samples showed detectable levels of endotoxin and, in the majority of those that did, the level was found to be low. Other workers have reported comparable endotoxin levels in DUWS and have attributed clinical significance to their findings. ${ }^{11}$ However, endotoxin levels of up to $300 \mathrm{EU} \mathrm{ml}^{-1}$ have been found in the saliva of normal healthy subjects. ${ }^{8}$ It is unlikely, therefore, that endotoxin concentrations of $<300 \mathrm{EU} \mathrm{ml}^{-1}$ will be of any clinical relevance.

The ATP assay method used here was found to be very simple to use, was portable and gave virtually instant results (within one minute) making it very suitable for use at the chairside. However, statistical analysis of the data showed no statistical correlation between TVC and ATP, while a large proportion of water samples with TVC greater than the EU potable water standard (100 CFU $\mathrm{ml}^{-1}$ ) gave low ATP results, making it impossible at present to set a discriminatory cut off point using this approach. Although the ATP method worked better at high TVC (ie as an indicator of gross microbial contamination) and gave good reproducibility in replicate samples, routine use of this assay may yield a large number of unacceptable false negative values (Fig. 1). Thus, although the ATP method has a number of advantages, in its present format it is too insensitive to be recommended for the routine monitoring of DUWS microbial contamination.

\section{CONCLUSION}

ATP levels and endotoxin levels were not found to correlate with TVCs in water derived from dental unit water systems. The ATP assay was simple to perform and could be suitable for chairside use if the sensitivity and specificity issues could be overcome. Culturable methods underestimate the total number of microbial cells in water samples but currently represents the most reliable method available for assessing microbial contamination of dental unit water lines.

This study was supported by a research placement grant awarded to MRF by the NHS Research and Development Directorate. The authors would like to acknowledge the assistance of i) Gareth Lang and Biotrace UK Ltd, for the supply of the Uni-Lite TM equipment and Aquatrace ATP analysis test kits, ii) the practitioners who provided the DUWS samples, and iii) Michelle Finney and Chris Johnson for technical assistance in the microbial counts and Alethea Cope and Julie Rogers for their guidance and analysis of the flow cytometry samples.

1. Amann R I, Ludwig W, Schleifer K H. Phylogenetic identification and in situ detection of individual microbial cells without cultivation. Microbiol Rev 1995; 59: 143-169.

2. Anon. ADA Council on Scientific Affairs. Dental unit water lines: approaching the year 2000. J Am Dent Assoc 1999; 130:1653-1664.

3. Barbeau J, Gauthier C, Payment P. Biofilms, infectious agents, and dental unit waterlines: a review. Can J Microbio/ 1998; 44: 1019-1028.

4. Colquhoun K O, Timms S, Fricker C R. A simple method for the comparison of commercially available ATP hygiene-monitoring systems. J Food Prot 1998; 61: 499-501.

5. Davidson C A, Griffith C J, Peters A C, Fielding L M. Evaluation of two methods for monitoring surface cleanliness, ATP bioluminescence and traditional hygiene swabbing. Luminescence 1999; 14: 33-38.

6. Douglas C W, Rothwell PS. Evaluation of a hygiene monitor for detection of contamination in dental surgeries. Br Dent J 1991; 170: 331-335.

7. Martin M V. The significance of the bacterial contamination of dental unit water systems. Br Dent J 1987; 163: 152-154.

8. Millns B, Martin M V, Williams M C. Raised salivary endotoxin concentration as a predictor of infection in paediatric leukemia patients. Oral Surg Oral Med Oral Path Oral Radiol Endodon 1999; 88: 50-55.

9. Pankhurst C L, Johnson N W, Woods R G. Microbial contamination of dental unit waterlines: the scientific argument. Int Dent J 1998; 48: 359-368.

10. Pederson ED, Stone M E, Ragain J C, Jr., Simecek, J. W. Waterline biofilm and the dental treatment facility: a review. Gen Dent 2002; 50: 190-195.

11. Putnins E E, Di Giovanni D, Bhullar A S. Dental unit waterline contamination and its possible implications during periodontal surgery. J Periodonto/2001; 72: 393-400.

12. Singh A, Pyle $B H_{\text {., }}$ McFeters $G$ A. Rapid enumeration of viable bacteria by image analysis. J Microbio/ Methods 1989; 10: 91-101.

13. Smith A J, Hood J, Bagg J, Burke FT. Water, water everywhere but not a drop to drink? BrDent J 1999; 186: 12-14

14. Tall B D, Williams H N, George KS, Gray R T, Walch M. Bacterial succession within a biofilm in water supply lines of dental air-water syringes. Can J Microbiol 1995; 41: 647-654.

15. Walker J T, Bradshaw D J, Bennett A M, Fulford M R, Martin M V, Marsh P D. Microbial biofilm formation and contamination of dental-unit water systems in general dental practice. App/ Environ Microbiol 2000; 66: 3363-3367. 